\title{
INWENTARYZACJA WCZESNOŚREDNIOWIECZNYCH ZNALEZISK PIENIĄDZA KRUSZCOWEGO W POLSCE
}

\author{
CATALOGING THE EARLY MEDIEVAL SILVER HOARDS AND COINS FROM POLAND
}

Authors presents the history of the cataloging the Early Medieval Silver Hoards (c. 550-1150) and Coins from Poland, starting with the first works of Joachim Lelewel from the first half of the $19^{\text {th }}$ century, through the series Polskie Skarby Wczesnośredniowieczne of the mid-twentieth century, to the newest series Frühmittelalterliche Münzfunde aus Polen. For to the newest series, the principles and rules are outlined regarding to the chronological and territorial frames. The rules for the finds and coin description are given. The basic data on the number of registered finds, their types and distribution are also provided.

KEY WORDS: Early Middle Ages, Poland, Hoards, Coins, Catalogue

W Instytucie Historii Kultury Materialnej, a potem w Instytucie Archeologii i Etnologii PAN były prowadzone badania również nad historią pieniądza kruszcowego. Głównym, ale nie jedynym, ośrodkiem tych badań był zlokalizowany w Krakowie Zakład Numizmatyki. Kierował nim wybitny orientalista, prof. Tadeusz Lewicki, co powodowało, że siłą rzeczy placówka ta zajmowała się głównie, ale nie wyłącznie, badaniem znalezisk monet orientalnych. Można dodać, że w takiej skali po raz pierwszy w Polsce (Lewicki 1969; Kmietowicz 1984). W efekcie powstał szereg monograficznych opracowań skarbów składających się wyłącznie lub w głównej mierze z dirhemów arabskich, względ- nie ich naśladownictw. Tytułem przykładu można wymienić klasyczne już monografie skarbów z Czechowa (Czapkiewicz i in. 1957), Klukowicz (Czapkiewicz i in. 1964) czy Zalesia (Kmietowicz i in. 1969; Dekówna i in. 1974). W ramach tego Zakładu powstała również praca doktorska poświęcona mennictwu wczesnośredniowiecznemu w Polsce (Suchodolski 1973). Podstawowa działalność dotyczyła jednak badania znalezisk monet, a także innych form pieniądza kruszcowego.

Oczywiście idea inwentaryzowania i badania takich znalezisk nie była nowa. Pionierem w tym zakresie był Joachim Lelewel, który w 1826 roku opublikował - odkryty zaledwie dwa lata wcze- 


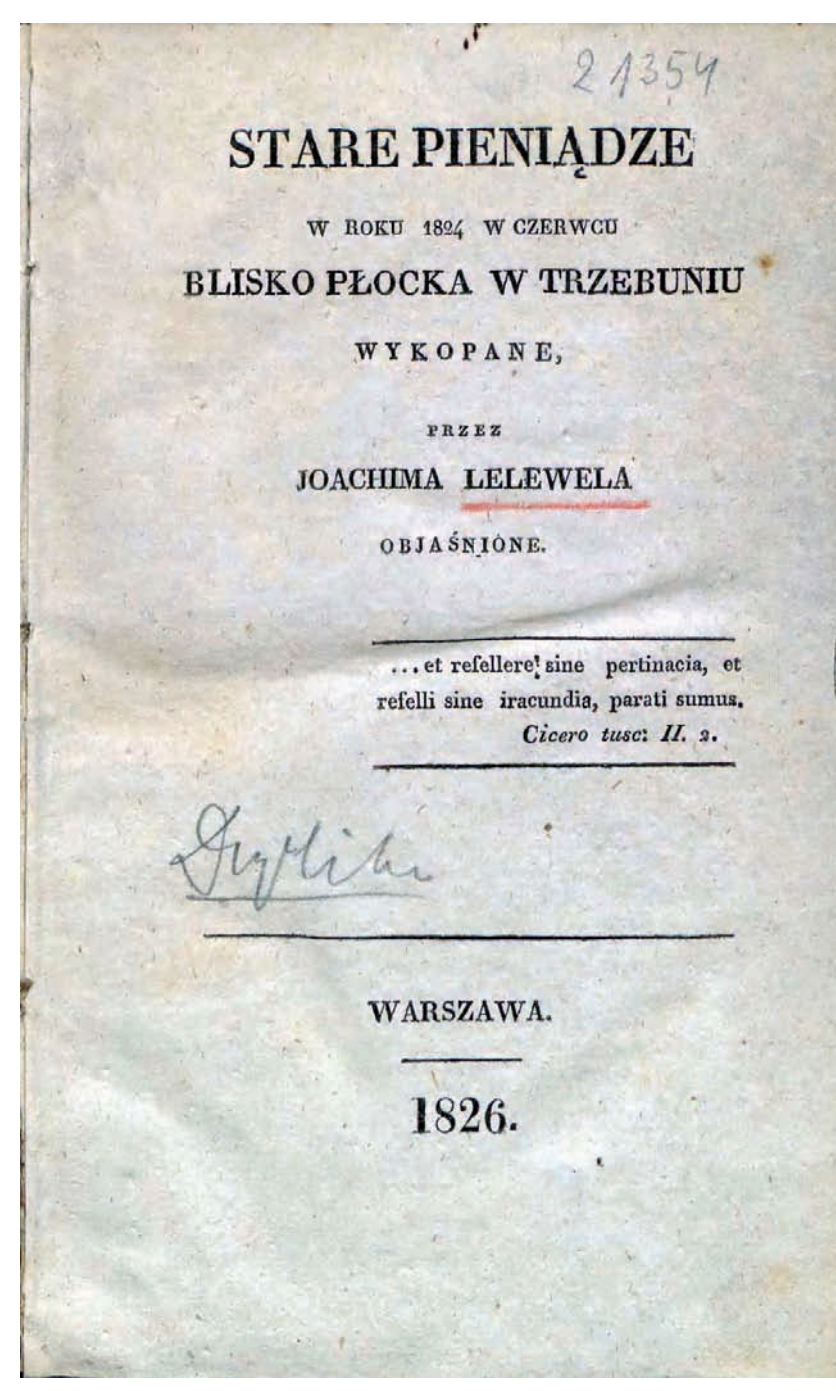

Ryc. 1. Strona tytułowa opracowania skarbu z Trzebunia, autorstwa Joachima Lelewela

Fig. 1. The title page of the Joachim Lelewel work on the Trzebun hoard

śniej - skarb monet z XI wieku znaleziony w Trzebuniu pod Płockiem (Lelewel 1826 - ryc. 1). Krok dalej poszedł o pokolenie młodszy Kazimierz Stronczyński, który opisał cały, znany wówczas zestaw skarbów wczesnośredniowiecznych, i to nawet dwukrotnie. Po raz pierwszy w 1847 roku (ryc. 2) i powtórnie w 1883 r. (ryc. 3), w znacznie rozszerzonym zakresie (Stronczyński 1847; 1883). „Rozbiorem wykopalisk objaśniał” on „monety pierwszych czterech wieków" i w efekcie stworzył pierwszą klasyfikację „dawnych monet Piastów”. W jego ślad poszedł w 1. połowie XX w. Marian Gumowski, który również dwukrotnie, w odstępie półwiecza, publikował swój inwentarz (Gumowski 1905; 1953).

Nowy etap rejestrowania i opracowywania znalezisk pieniądza kruszcowego - zgodnie z nowymi

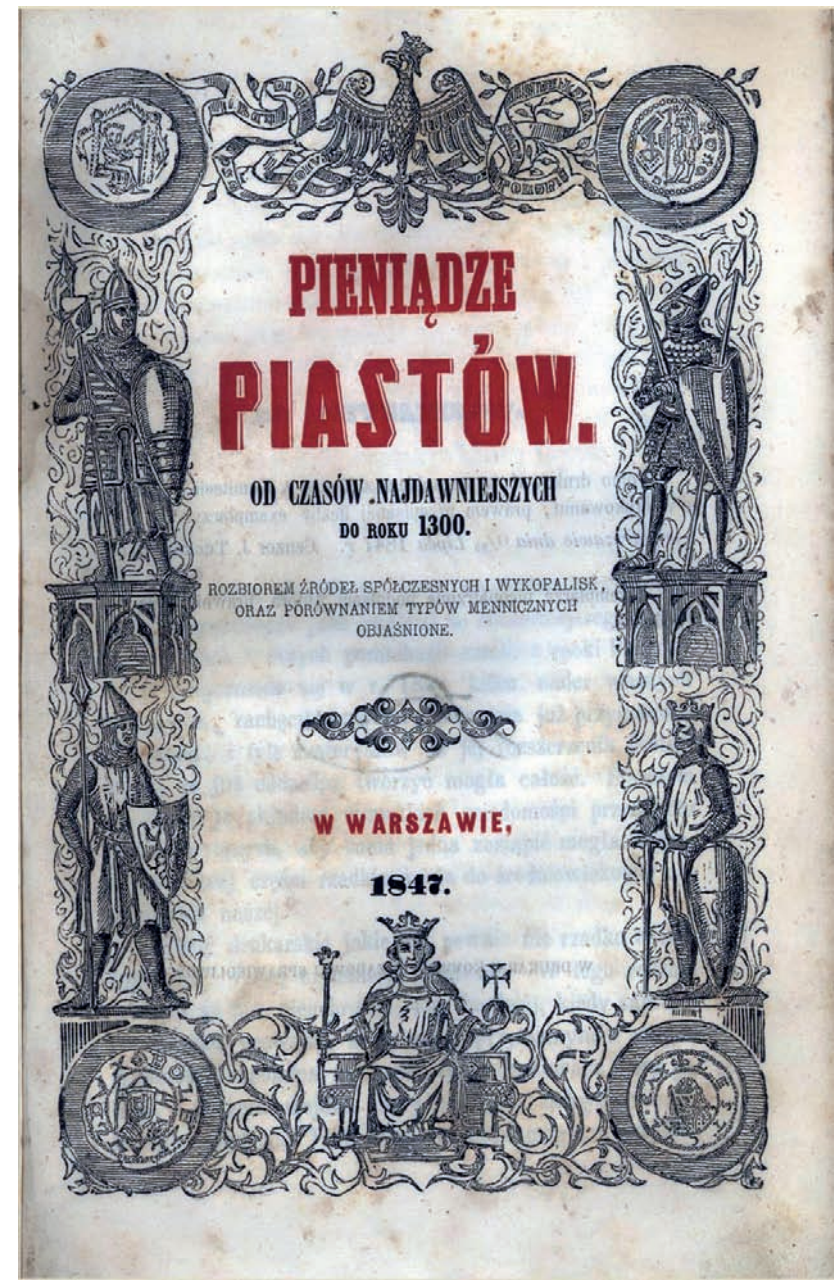

Ryc. 2. Strona tytułowa książki Kazimierza Stronczyńskiego z 1847 r.

Fig. 2. The cover of Kazimierz Stronczyński 1847 book

wymogami - nastąpił jednak dopiero po wojnie. Pionierami tych badań byli w Poznaniu tragicznie zmarły w 1951 r. Jacek Slaski (Slaski 1953) oraz kontynuujący jego prace Stanisław Tabaczyński (Tabaczyński 1958), a w Warszawie Ryszard i Teresa Kiersnowscy (Kiersnowski 1960). Głównym natomiast ośrodkiem, w którym powstał plan zinwentaryzowania znalezisk pieniądza kruszcowego w Polsce, był właśnie Zakład Numizmatyki naszego Instytutu. Inicjacja tych prac i potem ich realizacja w latach pięćdziesiątych i sześćdziesiątych XX w. nie przypadkowo zbiega się $\mathrm{z}$ badaniami milenijnymi. Były one finansowane ,z zasiłku Komitetu przygotowawczego obchodów tysiąclecia Państwa Polskiego".

Inwentaryzacja nie miała być celem samym w sobie i prowadzić jedynie do stworzenia bazy źródłowej. „Zakres podjętych badań - jak pisał w 1958 r. Stanisław Tabaczyński - jest znacznie 


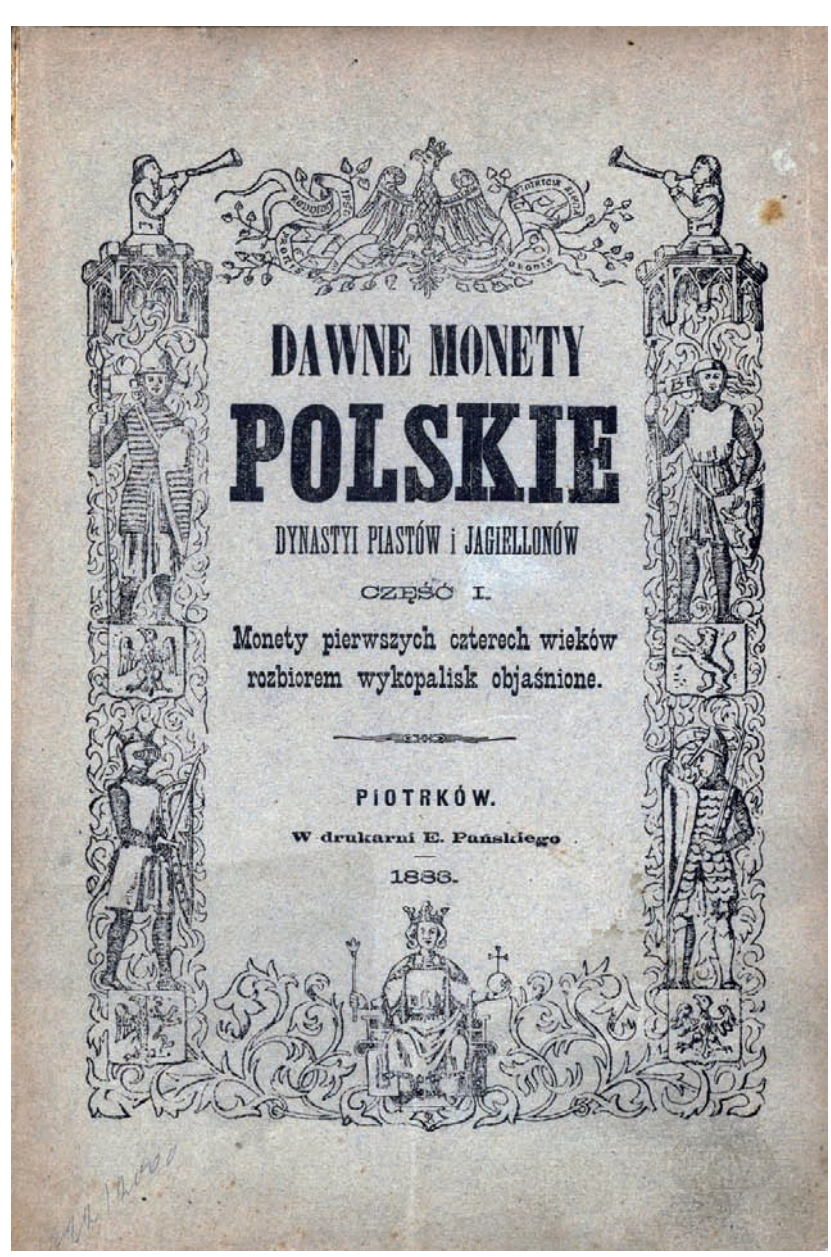

Ryc. 3. Strona tytułowa książki Kazimierza Stronczyńskiego z $1883 \mathrm{r}$.

Fig. 3. The cover of Kazimierz Stronczyński 1883 book

szerszy, zmierzają one bowiem do wszechstronnego, pełnego wykorzystania skarbu jako określonej kategorii źródła historycznego" (Tabaczyński 1958, 7). Całość materiału podzielono na 4 tomy obejmujące Wielkopolskę, Pomorze, Mazowsze i Polskę Środkową oraz Małopolskę i Śląsk. Ukazywały się one w latach 1959-1966 w ramach serii „Polskie skarby wczesnośredniowieczne. Inwentarze”, wchodzącej w skład serii nadrzędnej „Polskie Badania Archeologiczne", redagowanej przez Witolda Hensla. A oto ich wykaz:

I. Jacek Slaski i Stanisław Tabaczyński, Wczesnośredniowieczne skarby srebrne Wielkopolski. Materiaty. Polskie Badania Archeologiczne, t. 1, Polskie skarby wczesnośredniowieczne. Inwentarze, t. I, Warszawa-Wrocław 1959 (w skrócie PSW I).

II. Teresa i Ryszard Kiersnowscy, Wczesnośredniowieczne skarby srebrne z Pomorza. Materiaty. Polskie Badania Archeologiczne, t. 4,
Polskie skarby wczesnośredniowieczne. Inwentarze, t. II, Warszawa-Wrocław 1959 (PSW II - ryc. 4).

III. Anatol Gupieniec, Teresa i Ryszard Kiersnowscy, Wczesnośredniowieczne skarby srebrne z Polski Środkowej, Mazowsza i Podlasia. Materiały. Polskie Badania Archeologiczne, t. 10, Polskie skarby wczesnośredniowieczne. Inwentarze, t. III, Wrocław-Warszawa-Kraków 1965 (PSW III).

IV. Marian Haisig, Ryszard Kiersnowski, Janusz Reyman, Wczesnośredniowieczne skarby srebrne z Małopolski, Ślaska, Warmii i Mazur. Materiały. Uzupetnienia do t. I-III. Polskie Badania Archeologiczne, t. 12, Polskie skarby wczesnośredniowieczne. Inwentarze, t. IV, Wrocław-Warszawa-Kraków 1966 (PSW IVA, B i C).

Uzupełnieniem wymienionych powyżej tomów była praca Ryszarda Kiersnowskiego, Wczesnośredniowieczne skarby srebrne z Połabia z 1964 r.

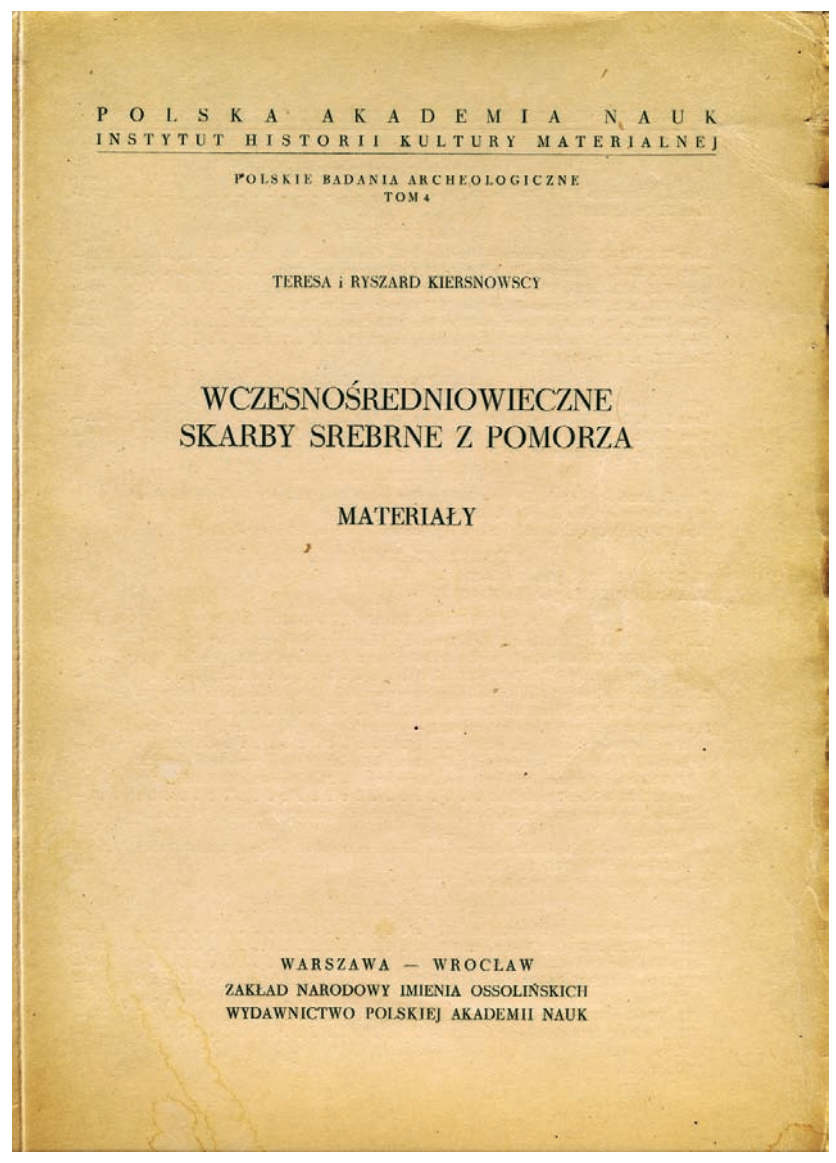

Ryc. 4. Strona tytułowa Inwentarza Polskich Skarbów Wczesnośredniowiecznych, tom II. Pomorze

Fig. 4. The book cover of the "Polskie Skarby Wczesnośredniowieczne. Inwentarze”, vol II. Pomerania 
I choć ze względów formalnych nie była ona częścią serii „Polskie skarby wczesnośredniowieczne. Inwentarze", to ukazywała całościowy, niezależny od współczesnych granic, charakter skarbów z ziem Słowiańszczyzny Zachodniej.

Inwentarze te po raz pierwszy uwzględniały nie tylko monety, ale również inne formy pieniądza kruszcowego, takie jak ozdoby całe i połamane, a także sztabki i tzw. placki, czyli srebro lane. Odnotowywano też obecność składników wyjątkowych, na przykład paciorków szklanych czy odważników. Zwracano uwagę również na formy zabezpieczenia (garnki i inne pojemniki), a także na sposób i kontekst ukrycia. Wbrew tytułowi natomiast uwzględniane były nie tylko skarby, czyli znaleziska gromadne, ale również tzw. znaleziska pojedyncze czy luźne. Rzecz ciekawa, że seria ta nie miała redaktora, a była firmowana przez raczej honorowy „Komitet redakcyjny”, składający się z wybitnych archeologów. Obowiązki redakcyjne pełnili sekretarze poszczególnych tomów (Lech Leciejewicz, Włodzimierz Szafrański i Maria Dekówna). Można się tylko domyślać, że inicjatorem i dobrym duchem całego przedsięwzięcia był najbardziej kompetentny w tym zespole, współautor trzech tomów, Ryszard Kiersnowski (dla Pomorza, Mazowsza oraz Warmii i Mazur, a także uzupełnień i indeksów). Poza nim i jego małżonką, a także już wymienionym Stanisławem Tabaczyńskim, w skład zespołu autorskiego wchodzili jeszcze Anatol Gupieniec (głównie dla Polski Środkowej i północnego Mazowsza), Janusz Reyman (dla Małopolski) i Marian Haisig (dla Śląska).

Kartograficzne opracowanie całego materiału zawartego w Polskich skarbach wczesnośredniowiecznych wraz $\mathrm{z}$ uzupełnieniami według stanu z 1973 roku przyniosła praca zbiorowa przygotowana przez zespół Polskiego Atlasu Archeologicznego Instytutu Historii Kultury Materialnej PAN. $\mathrm{Na}$ dwunastu mapach zlokalizowano miejsca odkrycia 468 skarbów i 198 znalezisk pojedynczych, niejednokrotnie korygując dane podane w literaturze (Gajewski i in. 1982 - ryc. 5).

Inwentarz był pionierski nie tylko w skali polskiej, ale również europejskiej i dobrze służył do badań archeologom, historykom i oczywiście numizmatykom (por. np. Kóčka-Krenz 1993; Suchodolski 2012; Adamczyk 2014). Jednak po ponad 30 latach był on już częściowo przestarzały i wymagał gruntownej modernizacji. Trzeba było dokonać poprawek zgodnie z nowym, obowiązującym stanem

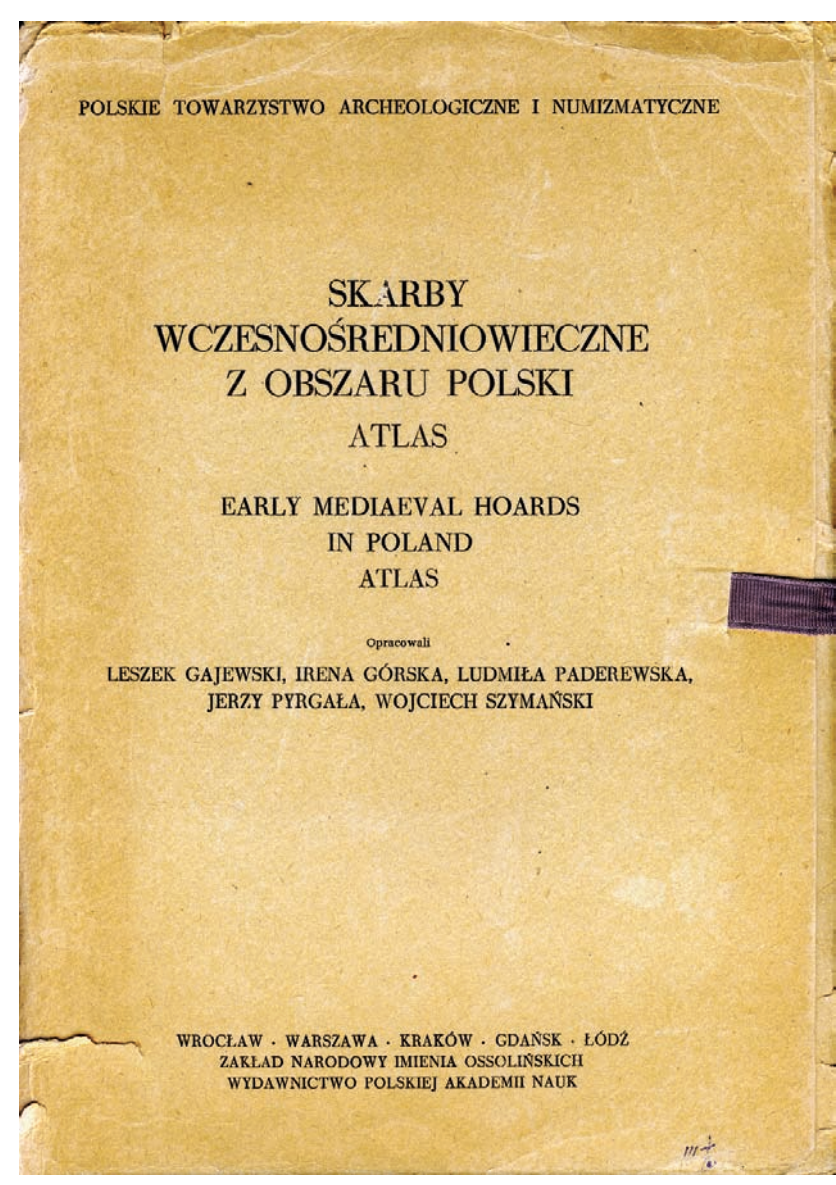

Ryc. 5. Strona tytułowa Atlasu skarbów wczesnośredniowiecznych z obszaru Polski z 1982 r.

Fig. 5. The book cover of the 1982 Atlas of the Early Medieval Hoards

wiedzy, wyeliminować pozycje dublujące się i uzupełnić o materiały wprawdzie już znane, ale jeszcze nie opracowane. Konieczne było też przeprowadzenie dalszych poszukiwań w zbiorach muzealnych, pracowniach archeologów i zasobach archiwalnych, i to zarówno krajowych, jak i zagranicznych, głównie niemieckich (Berlin, Stralsund, Brunszwik, Hanower, Hamburg, Münster, Monachium), ale też rosyjskich (Petersburg, Moskwa) i duńskim (Kopenhaga). Zasadniczy jednak przyrost materiału nastąpił dzięki nowym znaleziskom. Przybywały one w sposób lawinowy dzięki intensyfikacji rolnictwa (głęboka orka!) i prac budowlanych, a także badań archeologicznych, wreszcie na skutek używania wykrywaczy metali (ryc. 6). Trzeba nadto wziąć pod uwagę, że w ciągu tego czasu nastapił wielki postęp $\mathrm{w}$ badaniach nad monetami polskimi i obcymi, tak co do ich określania, jak i chronologii. Podobnie ma się rzecz z towarzyszącymi im ozdobami srebrnymi (por. recenzje poszczególnych 


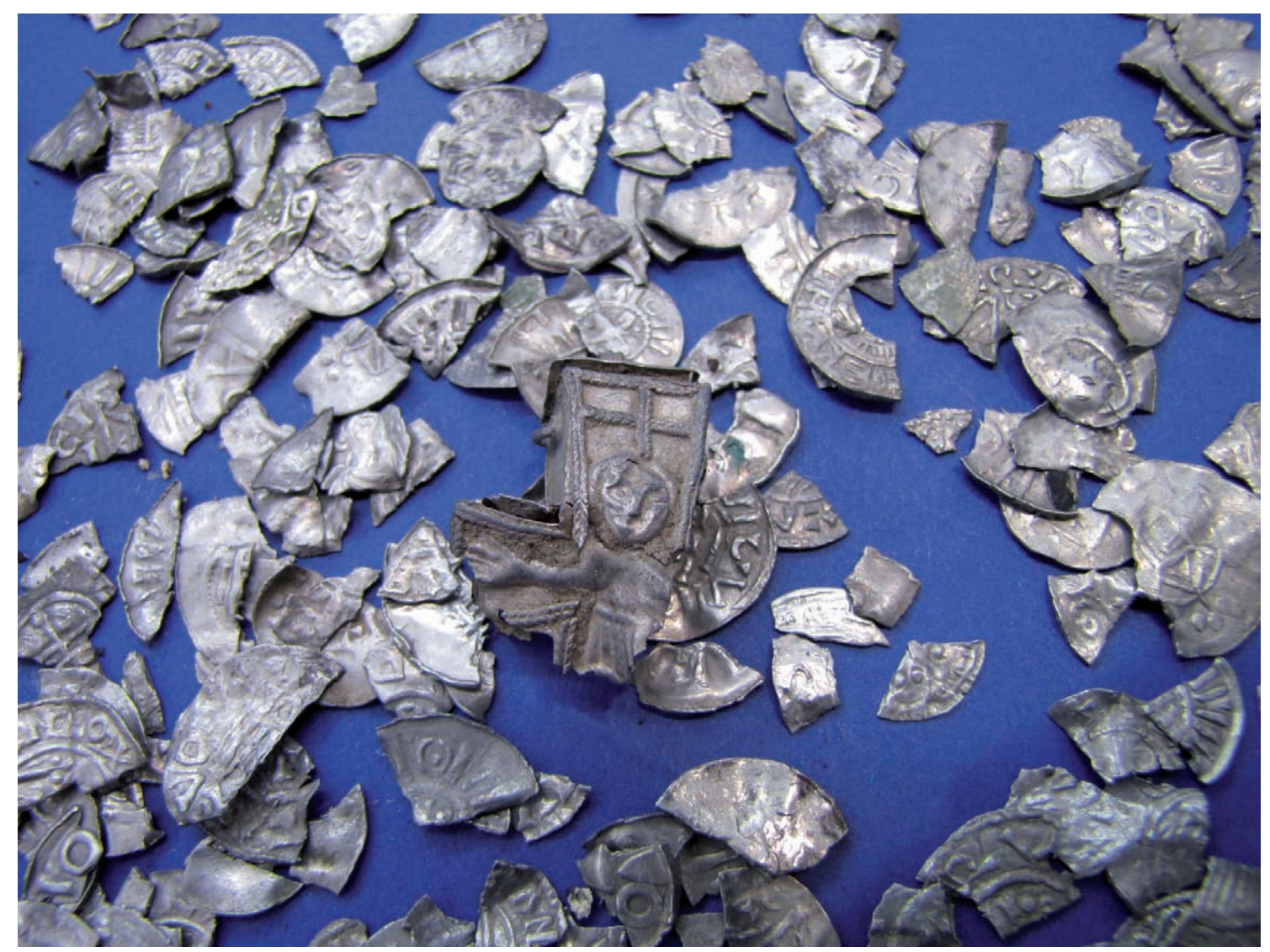

Ryc. 6. Skarb z Mózgowa na Warmii (Fot. M. Bogucki)

Fig. 6. Hacksilver hoard from Mózgowo in Warmia (Photo by M. Bogucki)

tomów, Suchodolski 1960; 1966, a zwłaszcza Suchodolski 2000, 163-165, gdzie mankamenty wymienione bardziej szczegółowo).

Zaszła również bardzo sprzyjająca okoliczność, a mianowicie pojawiło się zainteresowanie badaczy niemieckich naszymi materiałami - w pierwszym rzędzie monetami niemieckimi odkrytymi na terenie Polski. Wyrazem tego było zawarte w 1996 r. porozumienie między Instytutem Archeologii i Etnologii a Niemiecką Komisją Numizmatyczną co do wspólnego opracowania inwentarza znalezisk monet wczesnośredniowiecznych z ziem polskich. Tu pomoc ze strony Dr Petera Ilischa z Münster, wybitnego znawcy najliczniejszych w naszych znaleziskach monet niemieckich, okazała się bezcenna (Ilisch 2000).

Prace, bez dodatkowego wsparcia finansowego, posuwały się jednak powoli. Przełomowe znaczenie miało dopiero uzyskanie w 2000 r. dwuletniego grantu Komitetu Badań Naukowych na sfinansowanie tego projektu. W efekcie powstał nowy inwentarz w języku niemieckim, niestety okrojony ze względów finansowych o Śląsk i Małopolskę.
Kierownikiem grantu został Stanisław Suchodolski, a wykonawcami byli badacze młodszego pokolenia (por. Suchodolski 2000; 2006).

I. Wielkopolska: Arkadiusz Tabaka przy współudziale Borysa Paszkiewicza i z wykorzystaniem materiałów opracowanych przez Jerzego Pinińskiego (ze zbiorów Muzeum Archeologicznego i Etnograficznego w Łodzi).

II. Pomorze: Genowefa Horoszko i Jerzy Piniński oraz Warmia i Mazury: Mateusz Bogucki.

III. Mazowsze, Podlasie i Polska Środkowa: Dobrochna Gorlińska przy współudziale Stanisława Suchodolskiego i z wykorzystaniem materiałów opracowanych przez Jerzego Pinińskiego (ze zbiorów Muzeum Archeologicznego i Etnograficznego w Łodzi), a także przez Kunkę Szubert (ze zbiorów Państwowego Muzeum Archeologicznego w Warszawie).

Materiały orientalne (dirhemy arabskie i ich naśladownictwa, a także drachmy sasanidzkie) ze wszystkich dzielnic zostały opracowane przez Dorotę Malarczyk z Instytutu Filologii Orientalnej UJ. Natomiast ekspertem od najliczniejszych monet 
niemieckich był nadal Peter Ilisch, który jest też autorem niemieckiej wersji tekstu. $Z$ tego też powodu został on współautorem wszystkich tomów inwentarza.

Tak przygotowany inwentarz pozostał w wersji maszynopisu, nie było bowiem funduszy na dokończenie zadania i publikację całości. Więcej szczęścia miały inwentarze cząstkowe, obejmujące regiony południowe, realizowane $\mathrm{w}$ ramach osobnych grantów. W efekcie opublikowany został inwentarz dotyczący znalezisk ze Śląska, w dodatku zaopatrzony jeszcze w obszerne komentarze (Butent-Stefaniak, Malarczyk 2009). Inwentarz obejmujący znaleziska z Małopolski opracowała Bożena Reyman; pozostał on jednak w maszynopisie. Wszystkie te dokonania znacznie ułatwiły realizację trzeciego etapu prac nad wykończeniem i publikacją nowego inwentarza znalezisk. Etap ten realizował już Mateusz Bogucki, który przedstawi jego założenia i realizację.

Szansą na kontynuowanie prac nad inwentaryzacją znalezisk pieniądza kruszcowego w Polsce stało się powołanie w 2011 r. przez Ministerstwo Nauki i Szkolnictwa Wyższego programu grantowego zatytułowanego Narodowy Program Rozwoju Humanistyki i przyznanie finansowania na realizację projektu pt. Polskie skarby wczesnośredniowieczne - Inwentarz. Rejestracja znalezisk monet wczesnośredniowiecznych z obszaru Polski (VI-połowa XII w.), nr rej. NPRH 11 H11 019980. Celem tego projektu jest publikacja w języku o zasięgu międzynarodowym (niemieckim) wspomnianego inwentarza. Zadania tego podjął się kierujący grantem Mateusz Bogucki, który siłą rzeczy został głównym redaktorem tej publikacji. Wspomagają go Peter Ilisch oraz Stanisław Suchodolski.

Istotnym czynnikiem, który sprawił, że reedycja inwentarzy skarbów wczesnośredniowiecznych stała się nieodzowna, był i jest ciagły postęp w badaniach nad monetą $\mathrm{z}$ tego czasu. Tuż po II wojnie światowej stan wiedzy numizmatycznej opierał się w dużej mierze na klasycznych jeszcze pracach XIX-wiecznych. Obecnie liczne studia nad mennictwem europejskim, prowadzone niemal we wszystkich państwach starego kontynentu, doprowadzily do radykalnych zmian atrybucji monet. Określenie dawnych znalezisk według współczesnych standardów spowoduje, że badacze przestaną opierać się na nieaktualnej podstawie źródłowej.

Nie mniej ważnym czynnikiem, który skłonił nas do podjęcia trudu ponownego wydania inwen- tarzy, jest ogromny wzrost liczby znalezisk w ostatnich 20 latach, co wiąże się przede wszystkim z licznymi inwestycjami budowlanymi, wzmożeniem działalności archeologicznej oraz z upowszechnieniem się wykrywaczy metali. W 1973 roku badacze mieli informacje o 666 znaleziskach, w tym 468 skarbach i 198 monetach pojedynczych (Gajewski $\mathrm{i}$ in. 1982). Dziś wiemy o co najmniej 1151 znaleziskach, w tym 664 skarbach i 489 znaleziskach grobowych, a także pojedynczych. Co roku dokonywane są kolejne, liczne odkrycia.

W oparciu o dane zebrane $\mathrm{w}$ ramach wspomnianego już wcześniej grantu KBN, opracowano koncepcję przygotowania, przetworzenia i opublikowania materiałów. Celem projektu było przede wszystkim opublikowanie wszystkich znanych znalezisk (skarbów i pojedynczych) monet wczesnośredniowiecznych (VI-połowa XII w.), dokonanych w obecnych granicach Polski do 2013 roku włącznie. Podstawą stały się Inwentarze z lat 19591964 oraz nieopublikowane Inwentarze utworzone dzięki grantom $\mathrm{z}$ lat 2000-2003.

Do najważniejszych zadań należało:

- Określenie dawnych znalezisk i monet według współczesnych standardów;

- Uwzględnienie nowych znalezisk (z ziemi, magazynów, archiwów);

- Współpraca międzynarodowa (udział eksperta z Niemiec, wykorzystanie zbiorów i archiwów zagranicznych);

- Zilustrowanie jak największej liczby obiektów (atrybucje się zmieniają, zabytki nie).

Inwentaryzacją objęto znaleziska z okresu od VI do połowy XII wieku. Seria Frühmittelalterliche Münzfunde aus Polen (w skrócie FMP) wypełnia zatem lukę pomiędzy istniejącymi już (lub właśnie kończonymi) inwentarzami z jednej strony znalezisk monet antycznych (Ciołek 2001; 2007; 2008; Romanowski 2008), a z drugiej znalezisk monet późnośredniowiecznych (Kubiak, Paszkiewicz 1998).

Zmianą w stosunku do pierwszego wydania Inwentarza (PSW) jest obniżenie i zrównanie górnej granicy chronologicznej dla wszystkich tomów, która pierwotnie obejmowała również znaleziska z drugiej połowy XII, a nawet XIII wieku. Podobny zabieg został zastosowany w wydanym w $1982 \mathrm{r}$. Atlasie (Gajewski i in. 1982), który stanowił kartograficzne uzupełnienie pierwszej edycji PSW. Dodatkowym czynnikiem uzasadniającym posta- 
wienie takiego ograniczenia chronologicznego było ukazanie się inwentarza znalezisk monet średniowiecznych, w którym zebrano znaleziska pochodzące z lat 1150-1500 (Kubiak, Paszkiewicz 1998). Od zasady tej istnieje jednak kilka wyjątków. Zamieszczono bowiem w niniejszej reedycji kilka depozytów o chronologii sięgającej XII, a nawet XIII wieku. Są to jednakże skarby, które nie zawierają monet i w związku z tym nie zostały uwzględnione w inwentarzu autorstwa S. Kubiak i B. Paszkiewicza. Ujęcie tych znalezisk w serii FMP uzasadnione jest również tym, że swoim charakterem nawiązują one jeszcze do starszych skarbów wczesnośredniowiecznych. Owe nieliczne przypadki znane są głównie z terenów Polski wschodniej i północnowschodniej.

Chcąc sprawić, żeby nowe wydanie inwentarzy skarbów stało się łatwiejsze w odbiorze, w szczególności dla czytelnika zagranicznego, postanowiono oprzeć się na znanej i powszechnie stosowanej szwedzkiej serii inwentarzy znalezisk monet wczesnośredniowiecznych - Corpus nummorum saeculorum IX-XI qui in Suecia reperti sunt. Wzorzec ten jednak zmodyfikowano, biorąc pod uwagę nieco inny charakter znalezisk z ziem polskich, zupełnie odmienny (zdecydowanie gorszy) stan zachowania oryginalnych zabytków w dostępnych zbiorach muzealnych, a także konieczność częstego opierania się tylko na niekompletnych danych archiwalnych lub różnej dokładności publikacjach przedwojennych (ryc. 7). Zrezygnowano przede wszystkim z podawania średnic monet oraz systematycznego odnotowywania wtórnych śladów użytkowania. Dane te są bardzo często niekompletne i dochodzenie do nich spowodowałoby ogromne opóźnienie zakończenia całości inwentarzy (tak stało się w przypadku wspomnianych inwentarzy szwedzkich, które do dziś nie są ukończone). Średnice monet czytelnik może odczytać z tablic z ilustracjami, gdzie zamieszczono bogaty wybór przedmiotów ze znalezisk w skali 1:1. Rejestrację wtórnych śladów użytkowania ograniczono do odnotowywania perforacji monet i dodawania uszek. Zrezygnowano z rejestracji różnego rodzaju nacięć (tzw. pecksów i nicksów), śladów gięć i innych zabiegów, które powinny stać się elementem monografii skarbów.

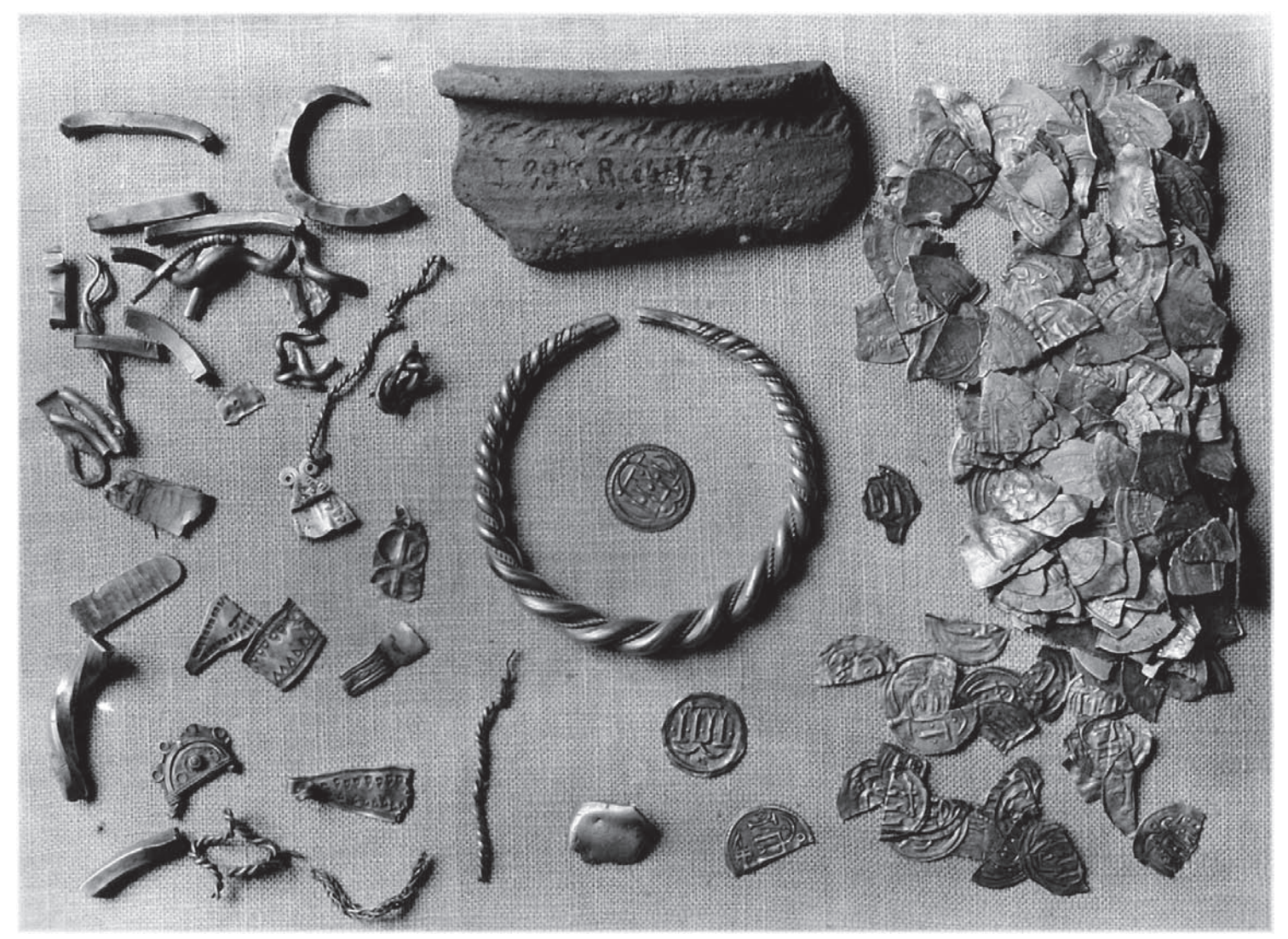

Ryc. 7. Skarb z Rybic na Pomorzu (archiwum Działu Archeologii Muzeum Narodowego w Szczecinie) Fig. 7. Hacksilver hoard from Rybice in Pomerania (archives of Archaeological Branch of the National Museum in Szczecin) 
Pominięto również teksty legend poszczególnych monet (w CNS podawano je dla wszystkich monet skandynawskich), starając się zrekompensować powyższe braki licznymi ilustracjami.

Ważną spuścizną po pierwszej edycji PSW oraz istotną różnicą w stosunku do CNS jest w miarę możliwości równorzędne potraktowanie monet i ozdób. O ile ich opis w CNS został zredukowany do absolutnego minimum (nie inwentaryzowano tam również depozytów niezawierających monet), o tyle w serii FMP każda ozdoba czy fragment srebra amorficznego otrzymał swój indywidualny numer, co pozwoli, mamy nadzieję, badaczom skarbów na bardziej kompleksową ich analizę.

Zróżnicowany stopień zachowania skarbów do naszych czasów powoduje, że często trudno zastosować do nich jednolity schemat opisu. Dotyczy to przede wszystkim znalezisk odkrytych jeszcze przed II wojną światową, które publikowane były tylko częściowo i według różnych zasad. Same zaś zabytki trafiały do różnych kolekcji, z których część się zachowała, część zaginęła, część zaś odnajdywana jest po latach, ale bez możliwości dopasowania do starszych publikacji. Dlatego też w wielu przypadkach odstępowano od sztywnego schematu opisu, tak by móc jak najwierniej odtworzyć skład pierwotnego zespołu.

Innym czynnikiem, który utrudnia zastosowanie ujednoliconego schematu, jest postęp wiedzy o sporej grupie monet anonimowych, czyli o naśladownictwach i denarach krzyżowych. Często trudno bowiem ocenić, czy dana moneta lub jakaś grupa monet przynależy do mennictwa niemieckiego, czeskiego, czy też polskiego. $\mathrm{Z}$ tego powodu zarówno naśladownictwa, jak i denary krzyżowe postanowiono wydzielić jako osobne grupy. Wyjątkiem są te naśladownictwa, które w świetle dostępnej wiedzy powstały w mennicach obcych niemieckich, czeskich czy skandynawskich. Czytelnik znajdzie je przypisane do odpowiedniego kraju. Inaczej postappiono z denarami krzyżowymi, które w dawniejszej literaturze polskiej (Gumowski 1939) przypisywane były polskim biskupom. Ze względu na homogeniczność tych monet, zestawiano je zawsze razem. Jednak i wśród nich starano się wyodrębnić te, które wybito w mennicach saskich, od tych, które w świetle nowych badań powstały na obszarze Polski - w mennicy kaliskiej, wrocławskiej, legnickiej czy bliżej niezidentyfikowanych ośrodkach wielkopolskich lub mazowieckich.
Należy podkreślić, że seria FMP jest reedycja, której podstawą są inwentarze PSW z lat 1959-1966. $\mathrm{Z}$ tego powodu dawni autorzy zostali uwzględnieni jako współtwórcy obecnej edycji.

Utrzymano język niemiecki inwentarzy, co wynika z wieloletniej już współpracy z Niemiecką Komisją Numizmatyczną oraz ze względu na fakt, że wśród zagranicznych użytkowników tej publikacji będą zapewne przeważać nasi zachodni sąsiedzi. Nie bez znaczenia były też powody praktyczne. Tłumaczenie bowiem istniejących już inwentarzy z niemieckiego na angielski byłoby bardzo czasochłonne.

Podstawową zmianą w stosunku do wcześniejszych wersji inwentarzy było założenie, że jest to spis, w którym każdy zinwentaryzowany obiekt powinien mieć swój unikalny numer, dzięki czemu inwentarz taki będzie mógł pełnić funkcję korpusu referencyjnego. Koncepcja taka została zaczerpnięta ze szwedzkiej serii CNS. W praktyce to właśnie ta zmiana okazała się najbardziej praco- i czasochłonna.

Zmodyfikowano również zakres przestrzenny, objęty inwentaryzacją - uwzględniono tylko i wyłącznie znaleziska odkryte w granicach współczesnego Państwa Polskiego - pominięto zatem część znalezisk ujętych w PSW II, które znajdują się wprawdzie na Pomorzu, ale na obszarze dzisiejszych Niemiec. Kolejną zmianą było uszczegółowienie granic wewnętrznych, które tak jak i w przypadku PSW są umowne i mają charakter techniczny - nie odzwierciedlają bezpośrednio ówczesnych podziałów terytorialnych, które w interesującym nas okresie ulegały zmianom. O ile w PSW granice pomiędzy dzielnicami przeprowadzono w sposób arbitralny, o tyle w FMP pomiędzy poszczególnymi dzielnicami zostały one oparte o granice współczesnych powiatów i gmin.

W stosunku do pierwszego wydania inwentarzy zmienił się również system podziału pracy. W PSW każdy tom miał osobnych autorów, natomiast w przypadku FMP zdecydowano się powierzać niektórym autorom nie poszczególne dzielnice, ale wybrane kategorie materiału źródłowego. I tak Peter Ilisch odpowiedzialny jest za określenia wszystkich monet niemieckich, Dorota Malarczyk określiła bądź zweryfikowała określenia wszystkich monet orientalnych, a Tomasz Nowakiewicz opracował ozdoby i srebro amorficzne. Znaleziska z każdej z dzielnic zostały opracowane przez jednego lub więcej autorów głównych, z którymi 
współpracowali dalsi, zazwyczaj przy konkretnych skarbach.

Całość została podzielona na pięć tomów:

Band I. FRÜHMITTELALTERLICHE MÜNZFUNDE AUS GROSSPOLEN

Autorzy: Tadeusz Szczurek, Peter Ilisch, Dorota Malarczyk, Tomasz Nowakiewicz, Arkadiusz Tabaka, Borys Paszkiewicz; współpraca: Paweł Kaźmierczak, Adam Kędzierski, Witold Nakielski i Mateusz Sikora, Warszawa 2017 (w skrócie FMP I)

Band II. FRÜHMITTELALTERLICHE MÜNZFUNDE AUS POMMERN

Autorzy: Genowefa Horoszko, Jerzy Piniński, Peter Ilisch, Dorota Malarczyk, Tomasz Nowakiewicz, współpraca: Mateusz Bogucki, Agnieszka Kowalówka i Michał Kulesza, Warszawa 2016 (FMP II)

Band III. FRÜHMITTELALTERLICHE MÜNZFUNDE AUS MASOWIEN, PODLACHIEN UND MITTELPOLEN

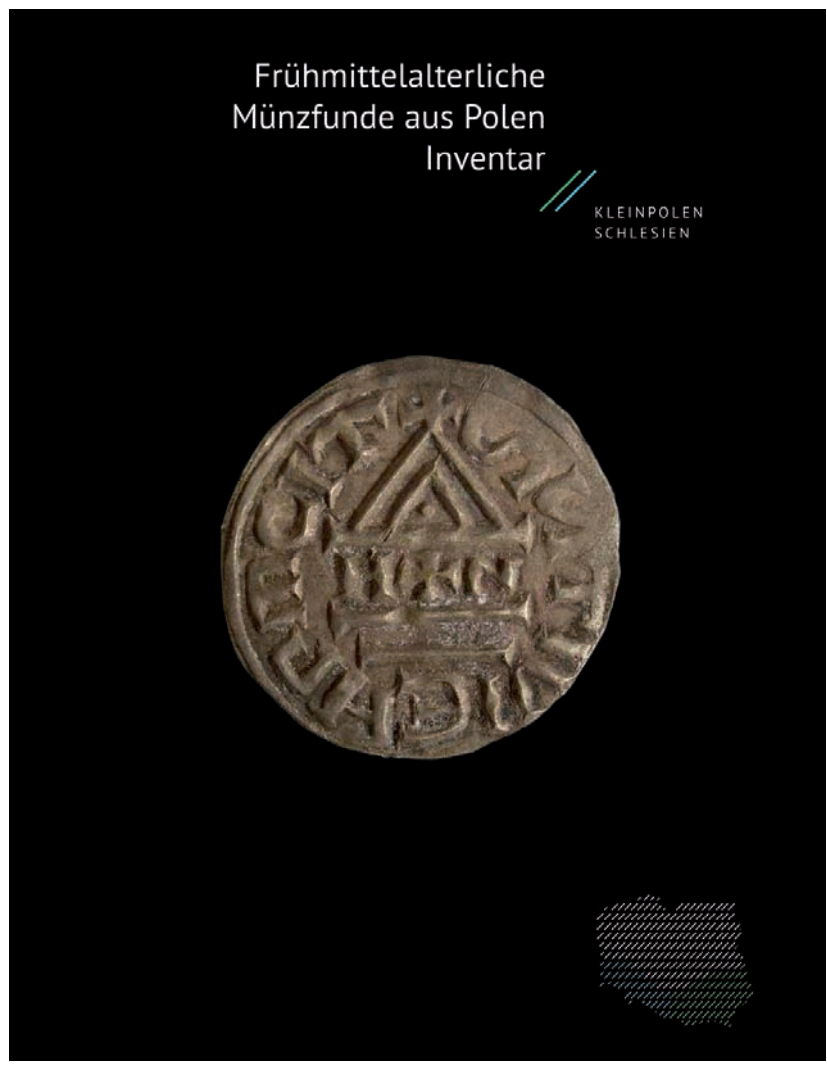

Ryc. 8. Strona tytułowa F rühmittelalterliche Münzfunde aus Polen. Inventar IV. 2013

Fig. 8. The book cover of the F rühmittelalterliche Münzfunde aus Polen. Inventar IV. 2013
Autorzy: Dobrochna Gorlińska, Stanisław Suchodolski, Mateusz Bogucki, Peter Ilisch, Dorota Malarczyk, Tomasz Nowakiewicz, współpraca: Piotr Chabrzyk, Kunka MitkowaSzubert, Jerzy Piniński, Andrzej Romanowski, Grzegorz Śnieżko, Maciej Widawski i Michał Zawadzki, Warszawa 2015 (FMP III)

Band IV. FRÜHMITTELALTERLICHE MÜNZFUNDE AUS KLEINPOLEN

Autorzy: Bożena Reyman-Walczak, Peter Ilisch, Dorota Malarczyk, Tomasz Nowakiewicz, współpraca: Mateusz Woźniak

FRÜHMITTELALTERLICHE MÜNZFUNDE AUS SCHLESIEN

Autorzy: Barbara Butent-Stefaniak, Peter Ilisch, Dorota Malarczyk, Tomasz Nowakiewicz, współpraca: Witold Nakielski, Warszawa 2013 (FMP IVA i B - ryc. 8)

Band V. FRÜHMITTELALTERLICHE MÜNZFUNDE AUS ERMLAND UND MASUREN

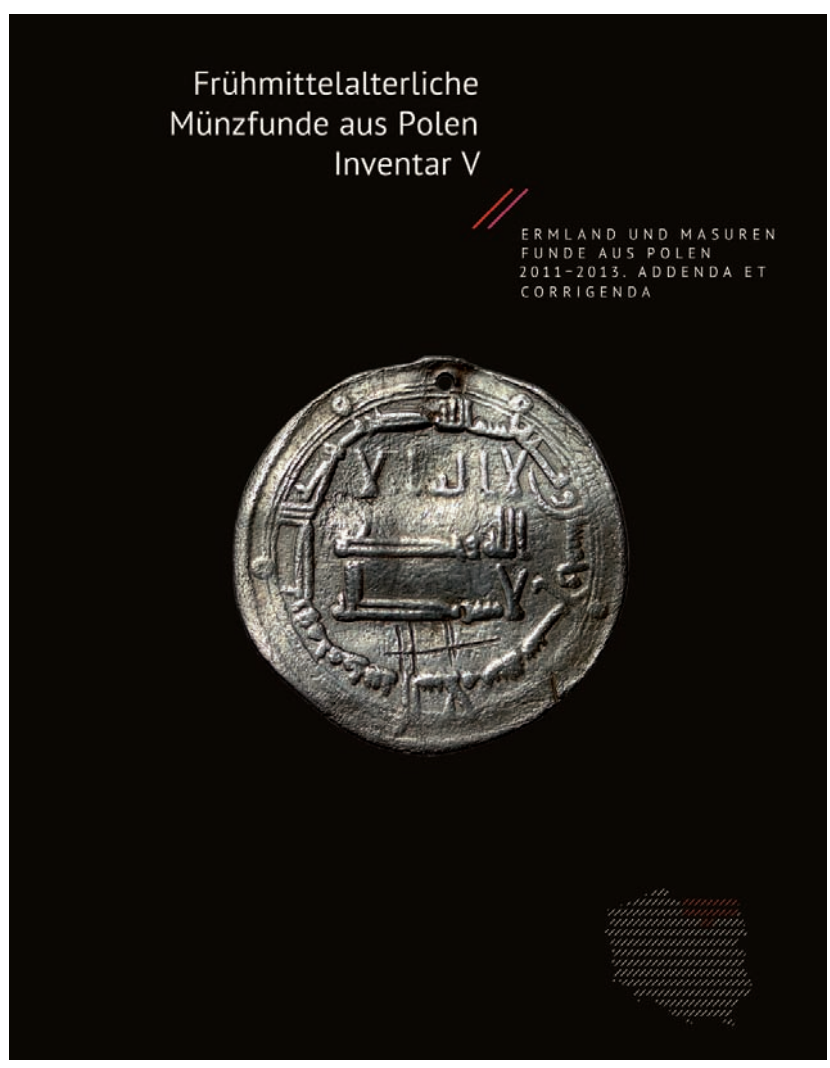

Ryc. 9. Strona tytułowa F rühmittelalterliche Münzfunde aus Polen. Inventar V. 2016

Fig. 9. The book cover of the F rühmittelalterliche Münzfunde aus Polen. Inventar V. 2016 
Autorzy: Mateusz Bogucki, Peter Ilisch, Dorota Malarczyk, Jerzy Piniński, Michał Kulesza i Tomasz Nowakiewicz

FRÜHMITTELALTERLICHE MÜNZFUNDE AUS POLEN, 2011-2013. ADDENDA ET CORRIGENDA

Autorzy: Mateusz Bogucki, Peter Ilisch, Dorota Malarczyk, Piotr Chabrzyk, Adam Kędzierski, Michał Kulesza, Tomasz Nowakiewicz i Roksana Wawrzczak, Warszawa 2016 (FMP VA i B - ryc. 9)

Zebrany we wszystkich tomach materiał liczy łącznie 1151 znalezisk. Ich rozprzestrzenienie w poszczególnych dzielnicach prezentuje tabela nr 1, w której uwzględniono również przyrost materiału w stosunku do PSW, liczebność monet i innych składników skarbów (ozdoby, srebro amorficzne, inne) oraz liczbę zilustrowanych obiektów.
Jak widać, przyrost materiału nie jest równomierny we wszystkich dzielnicach. Najwięcej znalezisk przybyło na obszarze Warmii i Mazur, co wynika głównie z dużej liczby odkryć monet pojedynczych, przeważnie w okolicach Elbląga, pojezierza iławskiego oraz mrągowskiego. Oprócz czynników historycznych (bliskość emporium Truso), dużą i pozytywną rolę odegrał w tym przypadku Wojewódzki Konserwator Zabytków, który aktywnie współpracuje ze stowarzyszeniami poszukiwaczy. W pozostałych przypadkach największy przyrost materiału ma miejsce w dzielnicach południowych - w Małopolsce i na Śląsku, gdzie przybyło go ok. 70\%. W dzielnicach centralnych (Mazowsze, Podlasie, Polska Środkowa, Wielkopolska) przyrost materiału jest już nieco mniejszy i wynosi ok. $60 \%$ w stosunku do PSW. Najmniej materiału przybyło na Pomorzu, bo zaledwie 25\%. Na obecnym etapie, bez szczegółowych analiz, trudno ocenić przyczy-

Tabela 1. Dane dotyczące liczby zinwentaryzowanych materiałów w ramach serii FMP.

Ze względu na trwanie prac, dane dla Wielkopolski są szacunkowe i mogą ulec zmianie

\begin{tabular}{|l|r|r|r|r|r|r|}
\hline \multicolumn{1}{|c|}{ Region } & $\begin{array}{c}\text { Liczba } \\
\text { znalezisk } \\
\text { PSW }\end{array}$ & $\begin{array}{c}\text { Liczba } \\
\text { znalezisk FMP }\end{array}$ & $\begin{array}{c}\text { Liczba } \\
\text { monet } \\
\text { FMP }\end{array}$ & $\begin{array}{c}\text { Inne } \\
\text { składniki } \\
\text { FMP }\end{array}$ & Razem FMP & \multicolumn{1}{c|}{$\begin{array}{c}\text { Ilustracje } \\
\text { FMP }\end{array}$} \\
\hline Małopolska & 69 & $121(+75 \%)$ & 14955 & 1628 & 16583 & 758 \\
\hline Śląsk & 64 & $110(+71 \%)$ & 13587 & 1751 & 15338 & 1080 \\
\hline Mazowsze & 139 & $220(+58 \%)$ & 57293 & 3925 & 61218 & 3406 \\
\hline Wielkopolska & 175 & ok. $284(+64 \%)$ & ok. 92086 & ok. 6197 & ok. 98283 & ok. 1500 \\
\hline Pomorze & 231 & $291(+25 \%)$ & 60289 & 5118 & 65407 & 2234 \\
\hline Warmia i Mazury & 19 & $57(+184 \%)$ & 4979 & 258 & 5237 & 934 \\
\hline „Polska & - & 70 & 2579 & 824 & 3403 & 1058 \\
\hline 2011-2013” & 697 & $1153(+65 \%)$ & ok. 245768 & ok. 19701 & ok. 2654699 & ok. 10970 \\
\hline Razem & & & & & &
\end{tabular}

Tabela 2. Podział materiału pod kątem rodzaju znalezisk. Ze względu na trwanie prac, dane dla Wielkopolski są szacunkowe i mogą ulec zmianie. Na szeregu stanowisk odnotowano zarówno znaleziska grobowe, jak i pojedyncze, stąd liczone one były podwójnie

\begin{tabular}{|l|r|r|r|r|}
\hline \multicolumn{1}{|c|}{ Region } & \multicolumn{1}{c|}{ skarby } & \multicolumn{1}{c|}{ grobowe } & pojedyncze & \multicolumn{1}{c|}{ Razem } \\
\hline Małopolska & 46 & 21 & 54 & 121 \\
\hline Śląsk & 63 & 16 & 31 & 110 \\
\hline Mazowsze & 123 & 25 & 72 & 220 \\
\hline Wielkopolska & ok. 197 & ok. 15 & ok. 72 & ok. 284 \\
\hline Pomorze & 190 & 20 & 88 & 291 \\
\hline Warmia i Mazury & 23 & - & 33 & 57 \\
\hline „Polska 2011-2013” & 22 & 1 & 47 & 70 \\
\hline Razem & 664 & 98 & 397 & 1153 \\
\hline
\end{tabular}


ny takich różnic. Wydaje się jednak, że mogą one w jakimś stopniu odzwierciedlać ogólną aktywność archeologiczną w Polsce.

Przyrost znalezisk nie jest równomierny również pod kątem kategorii. Najwięcej zarejestrowano bowiem monet pojedynczych bądź kumulatywnych. O ile do 1973 roku znanych było 198 znalezisk grobowych i pojedynczych (Gajewski et al. 1982), o tyle obecnie odnotowano ich 489 (tabela 2). Jeszcze w 2006 roku J. Łyszkowski odnotował 462 monety ze znalezisk osadniczych/ pojedynczych, obecnie natomiast naliczono ich co najmniej 2 871. Istotniejsze jednak, że w nowych materiałach bardzo wyraźnie ujawnił się nowy rodzaj znalezisk luźnych, tak zwanych znalezisk kumulatywnych. Mamy z nimi do czynienia wówczas, gdy na jednym stanowisku odkryto wiele pojedynczych monet. W tej kategorii na czoło wysuwają się przede wszystkim dobrze znane centra polityczne i osadnicze, takie jak Kraków, Tum pod Łęczyca, Giecz, Ostrów Lednicki, Kalisz, Krusz- wica, Wolin czy wreszcie Janów Pomorski-Truso z ponad tysiącem monet. Ale i na pomniejszych stanowiskach odkrywane są coraz liczniej zestawy pojedynczych monet. Warto w tym kontekście wspomnieć odkrycia w Bytomiu Odrzańskim, Ryczynie, Niemczy, Lądku, Grudusku, Radomiu, Zgłowiączce, Wawrzeńczycach, Budzistowie, Kałdusie czy Pawłówku.

Korzyści płynące $\mathrm{z}$ uaktualniania danych o dawniej odkrytych skarbach (ryc. 10) i ze zbierania informacji o nowych nie ulegają oczywiście wątpliwości. Wydaje się jednak, że największe zmiany $\mathrm{w}$ naszym postrzeganiu ekonomii Polski wczesnośredniowiecznej powoduje najbardziej widoczny, lawinowy przyrost znalezisk pojedynczych (ale też i grobowych - ryc. 11). Jest to bowiem zjawisko, które w zupełnie nowym świetle stawia takie kwestie, jak upieniężnienie rynków, ich dynamika terytorialna i chronologiczna, rola i funkcja, jaką pełniły monety w społeczeństwach wczesnośredniowiecznych. Udostępnienie źródeł do badań

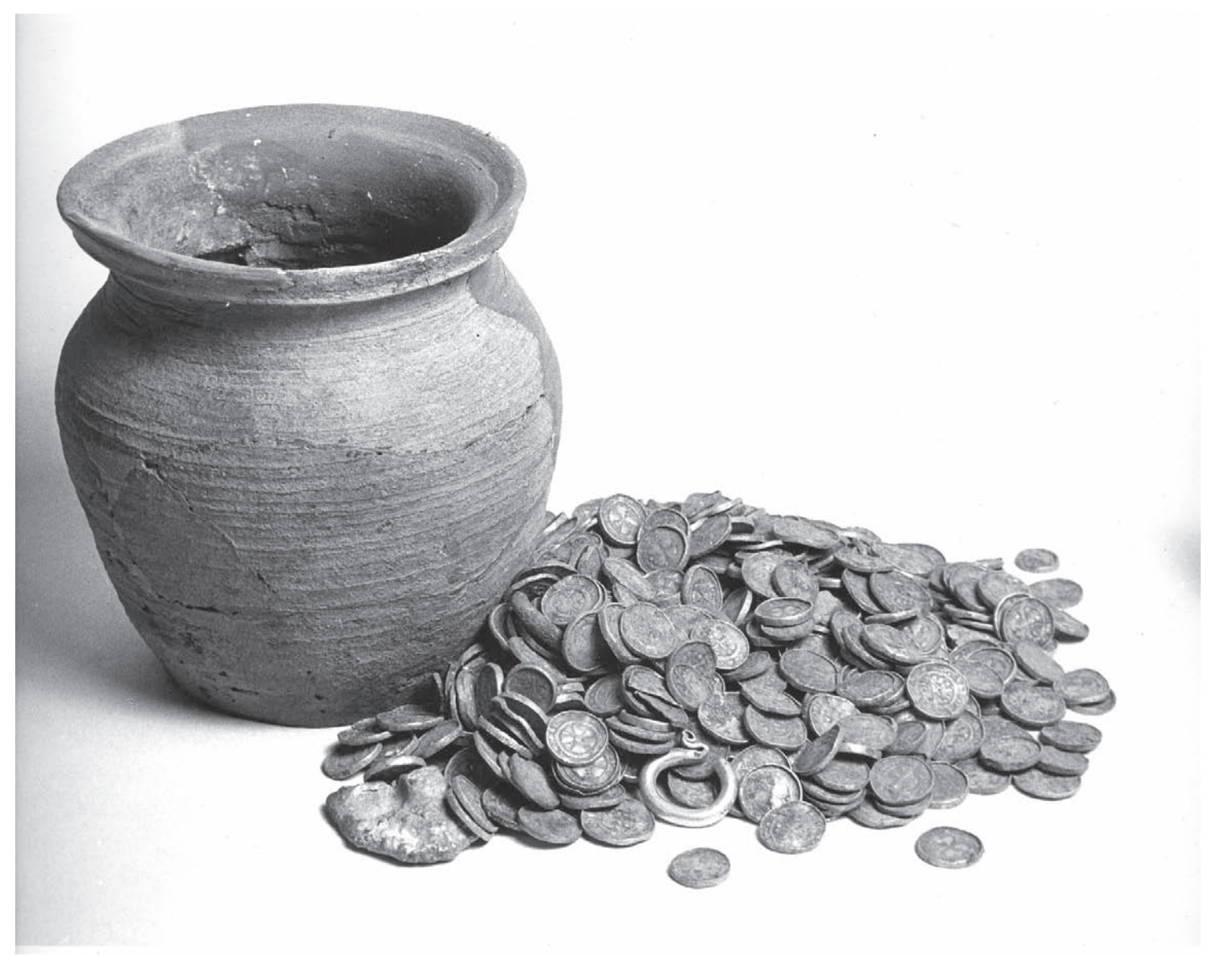

Ryc. 10. Skarb z Leźnicy Małej (archiwum Muzeum Archeologicznego i Etnograficznego w Łodzi) Fig. 10. Hacksilver hoard from Leźnica Mała in Central Poland (archiwum Muzeum Archeologicznego i Etnograficznego w Łodzi) 


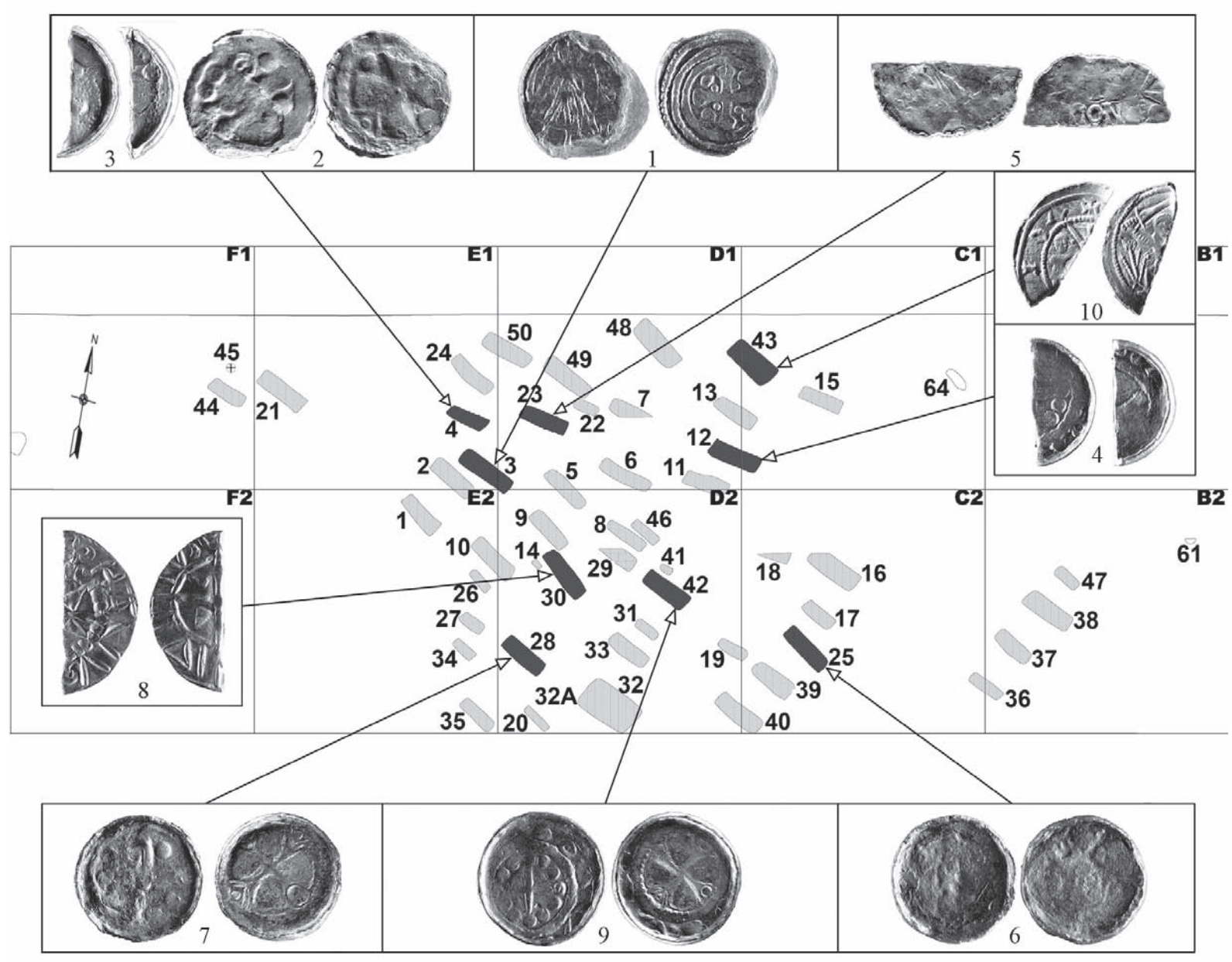

Ryc. 11. Monety z cmentarzyska w Prząłławiu (Śnieżko 2016)

Fig. 11. Coins from the cemetery at Prząsław (Śnieżko 2016)

wyżej wymienionych i wielu innych problemów było podstawowym celem serii FMP. Należy mieć nadzieję, że autorzy sprostali oczekiwaniom i dzię- ki nim studia nad mennictwem, obiegiem pieniądza i gospodarką wczesnośredniowieczną zyskają nowy, o wiele bogatszy wymiar.

\section{BIBLIOGRAFIA}

Adamczyk D. 2014. Silber und Macht. Fernhandel, Tribute und die piastische Herrschaftsbildung in nordosteuropäischer Perspektive (800-1100). Deutsches Historisches Institut Warschau, Quellen und Studien, Band 28, Wiesbaden.

Butent-Stefaniak B., Malarczyk D. 2009. Obieg pieniężny na Ślasku we wczesnym średniowieczu (od X do połowy XII wieku). Wrocław.

Ciołek, R. 2001. Katalog znalezisk monet rzymskich na Pomorzu. Światowit Supplement Series A: Antiquity VI. Warszawa.
Ciołek R. 2007. Die Fundmünzen der Römischen Zeit in Polen, Pommern. Collection Moneta 67, Wetteren.

Ciołek R. 2008. Die Fundmünzen der Römischen Zeit in Polen, Schlesien. Collection Moneta 83, Wetteren.

CNS - Malmer B., Rasmusson N. L., Jonsson K. (eds.), 1975. Corpus Nummorum Saeculorum IX-XI qui in Suecia reperti sunt. Catalogue of Coins from the Viking Age found in Sweden. Stockholm.

Czapkiewicz A., Lewicki T., Nosek S., Opozda-Czapkiewicz M. 1957. Skarb dirhemów arabskich z Czechowa. Warszawa-Wrocław. 
Czapkiewicz M., Gupieniec A., Kmietowicz A., Kubiak W. 1964. Skarb monet arabskich z Klukowicz powiat Siemiatycze. Wrocław-Warszawa-Kraków.

Dekówna M., Reyman J., Suchodolski S. 1974. Wczesnośredniowieczny skarb srebrny z Zalesia powiat Stupca, II. Monety bizantyjskie, monety zachodnioeuropejskie, ozdoby, podsumowanie. Wrocław-Warszawa-KrakówGdańsk.

FMP I - Szczurek T., Ilisch P., Malarczyk D., Nowakiewicz T., Tabaka A., Paszkiewicz B., Kaźmierczak P., Kędzierski A., Nakielski W., Sikora M. 2017. F rühmittelalterliche Münzfunde aus Grosspolen. (W:) M. Bogucki, P. Ilisch, S. Suchodolski (eds.), F rühmittelalterliche Münzfunde aus Polen. Inventar I. Warszawa.

FMP II - Horoszko G., Piniński J., Ilisch P., Malarczyk D., Nowakiewicz T., Bogucki M., Kowalówka A., Kulesza M. 2016. Frühmittelalterliche Münzfunde aus Pommern. (W:) M. Bogucki, P. Ilisch, S. Suchodolski (eds.), Frühmittelalterliche Münzfunde aus Polen. Inventar II. Warszawa.

FMP III - Gorlińska D., Suchodolski S., Bogucki M., Ilisch P., Malarczyk D., Nowakiewicz T., Chabrzyk P., Mitkowa-Szubert K., Piniński J., Romanowski A., Śnieżko G., Widawski M., Zawadzki M. 2015. Frühmittelalterliche Münzfunde aus Masowien, Podlachien und M ittel polen. (W:) M. Bogucki, P. Ilisch, S. Suchodolski (eds.), Frühmittelalterliche Münzfunde aus Polen. Inventar III. Warszawa.

FMP IV.A - Reyman-Walczak B., Ilisch P., Malarczyk D., Nowakiewicz T., Wożniak M. 2013. Frühmittelalterliche Münzfunde aus Kleinpolen. (W:) M. Bogucki, P. Ilisch, S. Suchodolski (eds.), F rühmittelalterliche Münzfunde aus Polen. Inventar IV. Warszawa, 19222.

FMP IV.B - Butent-Stefaniak B., Ilisch P., Malarczyk D., Nowakiewicz T., Nakielski W. 2013. F rühmittelalterliche Münzfunde aus Schlesien. (W:) M. Bogucki, P. Ilisch, S. Suchodolski (eds.), Frühmittelalterliche Münzunde aus Polen. Inventar IV. Warszawa, 225494.

FMP V.A - Bogucki M., Ilisch P., Malarczyk D., Piniński J., Kulesza M., Nowakiewicz T. 2016. F rühmittelalterliche Münzfunde aus Ermland und Masuren, (W:) M. Bogucki, P. Ilisch, S. Suchodolski (eds.), F rühmittelalterliche Münzfunde aus Polen. Inventar V. Warszawa, 19-186.

FMP V.B - Bogucki M., Ilisch P., Malarczyk D., Chabrzyk P., Kędzierski A., Kulesza M., Nowakiewicz T., Wawrzczak R. 2016. Frühmittelalterliche Münzfunde aus Polen 2011-2013. Addenda et Corrigenda, (W:) M. Bogucki, P. Ilisch, S. Suchodolski (eds.). F rühmit- telalterliche Münzfunde aus Polen. Inventar V. Warszawa, 189-340.

Gajewski L., Górska I., Paderewska L., Pyrgała J., Szymański W. 1982. Skarby wczesnośredniowieczne z obszaru Polski. Atlas. Wrocław-Warszawa-Kraków-GdańskŁódź.

Gumowski M. 1905. Wykopaliska monet polskich z Xi XI wieku. Kraków (odb. z Rozpr. Wydz. hist. fil. Ak. Um. 48).

Gumowski M. 1939. Corpus nummorum Poloniae, T. I. Monety X $i$ XI w., Kraków.

Gumowski M. 1953. Polskie skarby monet X-XI wieku (Materiały). Warszawa.

Ilisch P. 2000. Hochmittelalterliche Münzfunde aus dem Gebiet des heutigen Polens - ein gemeinsames Projekt. (W:) R. Cunz (ed.), Concordia ditat. 50 Jahre Numismatische Kommission der Länder in der Bundesrepublik Deutschland 1950-2000. Numismatische Studien 13. Hamburg, 203-207.

Kiersnowski R. 1960. Pieniadz kruszcowy w Polsce wczesnośredniowiecznej. Warszawa.

Kiersnowski R. 1964. Wczesnośredniowieczne skarby srebrne z Polabia, Polskie Badania Archeologiczne 11, Wrocław-Warszawa-Kraków.

Kmietowicz A. 1984. W trzydziestolecie powstania Zakładu Numizmatyki w Krakowie 1954-1984. Kwartalnik Historii Kultury Materialnej 32/3, 449-456.

Kmietowicz A., Kubiak W. 1969. Wczesnośredniowieczny skarb srebrny z Zalesia powiat Stupca, I, M onety arabskie. Wrocław-Warszawa-Kraków.

Kóčka-Krenz H. 1993. Biżuteria północno-zachodnio-stowiańska we wczesnym średniowieczu. Uniwersytet im. A. Mickiewicza w Poznaniu, Seria Archeologiczna 40. Poznań.

Kubiak S., Paszkiewicz B. 1998. Znaleziska monet z lat 1146-1500 z terenu Polski. Inwentarz. Poznań.

Lelewel J. 1826. Stare pieniadze w roku $1824 w$ czerwcu blisko Ptocka w Trzebuniu wykopane. Warszawa.

Lewicki T. 1969. Dzieje polskich badań w zakresie numizmatyki orientalnej. (W:) Szkice z dziejów polskiej orientalistyki III. Warszawa, 135-172.

Łyszkowski J. 2006. Odzwierciedlenie obiegu pieniężnego we wczesnym średniowieczu przez znaleziska drobne. Wiadomości Numizmatyczne 50/1 (180), 3-26.

PSW I - Slaski J., Tabaczyński S. 1959. Wczesnośredniowieczne skarby srebrne z Wielkopolski, Polskie Badania Archeologiczne 1. Warszawa-Wrocław.

PSW II - Kiersnowscy T. i R. 1959. Wczesnośredniowieczne skarby srebrne z Pomorza, Polskie Badania Archeologiczne 4, Warszawa-Wrocław. 
PSW III - Gupieniec A., Kiersnowscy T. i R. 1965. Wczesnośredniowieczne skarby srebrne z Polski Środkowej, Mazowsza i Podlasia, Polskie Badania Archeologiczne 10, Wrocław.

PSW IV.A-Reyman J. 1966. Wczesnośredniowieczne skarby srebrne z Małopolski. (W:) Wczesnośredniowieczne skarby srebrne z Małopolski, Ślaska, Warmii i Mazur, Polskie Badania Archeologiczne 12, Wrocław-Warszawa-Kraków, 7-32.

PSW IV.B - Haisig M. 1966. Wczesnośredniowieczne skarby srebrne ze Ślaska. (W:) Wczesnośredniowieczne skarby srebrne z Małopolski, Ślaska, Warmii i Mazur, Polskie Badania Archeologiczne 12, Wrocław-Warszawa-Kraków, 33-66.

PSW IV.C - Kiersnowski R. 1966. Wczesnośredniowieczne skarby srebrne z Warmii i Mazur. (W:) Wczesnośredniowieczne skarby srebrne z Małopolski, Ślaska, Warmii i Mazur, Polskie Badania Archeologiczne 12, Wrocław-Warszawa-Kraków, 67-78.

Romanowski, A. 2008. Die Fundmünzen der Römischen Zeit in Polen. Rechtsufriges Masowien und Podlachien. Collection Moneta 84, Wetteren.

Slaski J. 1953. Wielka własność ziemska na obszarze wczesnośredniowiecznej kasztelanii gieckiej w X i XI wieku (Wczesnopolskie skarby srebrne jako materiały do społeczno-gospodarczej analizy osadnictwa). Przegląd Archeologiczny 9, 271-279.

Stronczyński K. 1847. Pieniadze Piastów od czasów najdawniejszych do roku 1300 rozbiorem źródeł spółczesnych $i$ wykopalisk oraz porównaniem typów menniczych objaśnione. Warszawa.

Stronczyński K. 1883. Dawne monety polskie dynastyi Piastów i Jagiellonów. Cz. I. Monety czterech pierw- szych wieków rozbiorem wykopalisk objaśnione. Piotrków.

Suchodolski S. 1960. [Rec.] J. Slaski, S. Tabaczyński, Wczesnośredniowieczne skarby srebrne Wielkopolski. Materiały, Warszawa-Wrocław 1959. Wiadomości Numizmatyczne 4, 119-121.

Suchodolski S. 1966. [Rec.] A. Gupieniec, T. i R. Kiersnowscy, Wczesnośredniowieczne skarby srebrne z Polski Środkowej, Mazowsza i Podlasia. Materiały, Wrocław-Warszawa-Kraków 1965; M. Haisig, R. Kiersnowski, J. Reyman, Wczesnośredniowieczne skarby srebrne z Małopolski, Ślaska, Warmii i Mazur. Materiały, Wrocław-Warszawa-Kraków 1966. Wiadomości Numizmatyczne 10, 252-256

Suchodolski S. 1973. Mennictwo polskie w XI i XII wieku. Wrocław-Warszawa-Kraków-Gdańsk.

Suchodolski S. 2000. Reedycja inwentarza znalezisk monet wczesnośredniowiecznych z obszaru Polski (VIpołowa XII w.). Wiadomości Numizmatyczne 44/2, 161-170.

Suchodolski S. 2006. Program reedycji inwentarza znalezisk monet wczesnośredniowiecznych z ziem polskich (VI-połowa XII wieku). (W:) W. Chudziak, S. Moździoch (red.), Stan i potrzeby badań nad wczesnym średniowieczem w Polsce - 15 lat później. Toruń, 4150.

Suchodolski S. 2012. Numizmatyka średniowieczna. Moneta źródłem archeologicznym, historycznym i ikonograficznym. Warszawa.

Tabaczyński S. 1958. Z badań nad wczesnośredniowiecznymi skarbami srebrnymi Wielkopolski. WarszawaWrocław.

\section{CATALOGING THE EARLY MEDIEVAL SILVER HOARDS AND COINS FROM POLAND}

\section{SUMMARY}

Research on the history of Early Medieval metal money has been conducted at the Institute of Archaeology and Ethnology almost from its beginning. The main center of this research was the Department of Numismatics in Cracow, led by the orientalist, prof. Tadeusz Lewicki. As a result, a series of monographs were published on hoards focusing exclusively or mainly on Arabic dirhams (Czapkiewicz et al. 1957; Czapkiewicz et al. 1964; Kmietowicz et al. 1969; Dekówna et al. 1974).

Of course, the idea of cataloging and studying such finds was not new. Joachim Lelewel, a pioneer in this kind of research in Poland, published an $11^{\text {th }}$ century hoard found in Trzebuń near Płock (Lelewel 1826). Next came Kazimierz Stronczyński, who described the entire set of early medieval hoards known at the time (Stronczyński 1847; 1883). In his footsteps came Marian Gumowski in the first half of the 20th century (Gumowski 1905; 1953).

The next stage of recording and studying the coin and hoard finds from Poland came after the war. The pioneers of this research were Jacek Slaski (1953), Stanisław Tabaczyński (1958) and Ryszard and Teresa Kiersnowscy (Kiersnowski 1960). All this material was divided into 
4 volumes covering Wielkopolska; Pomerania; Mazovia and Central Poland; and Małopolska, Silesia and Masuria (PSW I-IV). These inventories included not only coins, but also other hoard components - silver ornaments and bars, silver scrap, glass beads and much besides. Attention was also paid to the forms of protection (pots and other containers) as well as the method of deposition and the archaeological context. Contrary to the title, not only hoards but also the single or loose coin finds have been cataloged. Cartographic elaboration of the entire material collected in the PSW (with the additions up to 1973) was published as Skarby wczesnośredniowieczne z obszaru Polski. Atlas (Gajewski et al. 1982).

After more than 30 years, the old inventories were partly outdated and required extensive modernization. In 1996, the IAE PAS signed an agreement with the German Numismatic Commission concerning the joint preparation of inventories of the early medieval coin finds from Polish lands. Most important was the help of Dr. Peter Ilisch of Münster, the eminent expert on the most numerous German coins present in our finds. In 2000, a two-year grant from the Scientific Research Committee was awarded. As result a typescript was prepared in German, but for financial reasons excluding Silesia and Małopolska. Stanisław Suchodolski supervised the work, and the authors were researchers of the younger generation (see Suchodolski 2000; 2006; Ilisch 2000).

As a result of separate grants, inventories of finds from Małopolska and Silesia were prepared. The Silesian volume was published with extensive comments (ButentStefaniak, Malarczyk 2009). Bożena Reyman's inventory of Małopolska finds remained in typewriting. All these accomplishments have facilitated the completion of the third stage of finishing and publishing the new inventories.

The next stage started in 2011, when a grant from the Ministry of Science and Higher Education was awarded to publish the entire inventories in German. This task was undertaken by Mateusz Bogucki, who is supervising all the works and became the main editor of this publication. He is supported by Peter Ilisch and Stanisław Suchodolski.

An important factor that made the reedition of the inventories necessary has been and continues to be a steady advance in coinage research since then and a huge increase in the number of finds over the last 20 years, primarily due to numerous construction investments, an increase in archaeological activity and with the widespread use of metal detectors. In 1973 there were 468 hoards and 198 single coin finds recorded (Gajewski et al. 1982). Today we know of at least 1,151 finds, including 664 hoards and 489 single and grave finds.
The purpose of the new project is to publish all known early medieval hoards and coin finds (6th-middle of the 12th century), made within the current borders of Poland through 2013. Inventories from 1959-1964 and inventories created by the 2000-2003 grant became the basis for the new edition. It should be emphasized that the Frühmittelalterliche Münzfunde aus Polen (FMP) series is a rewriting based on PSW inventories from 1959-1966. For this reason, former authors have been included as contributors to the current edition. The FMP series fills the gap between the already existing (or just finished) inventories of ancient coin finds on the one hand (Ciołek 2001; 2007; 2008; Romanowski 2008) and late medieval coins on the other (Kubiak, Paszkiewicz 1998). The basic change over previous inventories was the assumption that each item (coin, ornaments, bars, others) should have a unique number, so that the inventory could serve as a reference corpus. The concept was taken from the Swedish CNS series.

The material collected in all five volumes counts for a total of 1,151 finds. The largest increase was recorded in single or cumulative coins. In 1973 there were 198 grave and single finds (Gajewski et al. 1982), while 489 are recorded now. In 2006, Jakub Łyszkowski noted 462 single coins, now there are at least 2,871 coins recorded. In the new material, a new type of loose find, so-called cumulative finds, have emerged - when many single coins were discovered in a single archaeological site. In this category, well-known political and settlement centers such as Kraków, Tum near Łęczyca, Giecz, Ostrów Lednicki, Kalisz, Kruszwica, Wolin and finally Janów Pomorski (Truso) with over a thousand coins come to the fore. But in smaller sites, more and more sets of single coins are discovered. In this context, it is worth mentioning the discoveries in Bytom Odrzański, Ryczyn, Niemcza, Ląek, Grudusk, Radom, Zgłowiączka, Wawrzeńczyce, Kołobrzeg-Budzistowo, Kałdus and Pawłówek.

The benefits of updating the data on previously known hoards and collecting information about new ones are of course uncertain. It seems, however, that the greatest changes in our perception of the early medieval Polish economy are due to the increase of single and grave finds. This is a phenomenon that places such issues as market exchange, monetization, their territorial and chronological dynamics, the role and the function of coins in early medieval societies in a completely new light. Providing sources for the aforementioned research and many other problems was the primary goal of the FMP series. It is hoped that the authors will meet the expectations and that the studies of coinage, money circulation and early medieval economy will gain a new, much richer dimension. 
Adresy Autorów:

Prof. dr hab. Stanisław Suchodolski

Instytut Archeologii i Etnologii PAN

Al. Solidarności 105

00-140 Warszawa

e-mail: suchodol7@gmail.com

Dr hab. Mateusz Bogucki, prof. PAN

Ośrodek Archeologii Średniowiecza Krajów Nadbałtyckich

Instytut Archeologii i Etnologii PAN

ul. Kuśnierska 12/12a

70-536 Szczecin

e-mail: matbogu@yahoo.com 